Crop Breeding and Applied Biotechnology 13: 151-157 2013

Brazilian Society of Plant Breeding. Printed in Brazil

ARTICLE

\title{
Optimizing the number of progenies and replications in plant breeding experiments
}

\author{
João Luís da Silva Filho ${ }^{*}$
}

Received 05 June 2012

Accepted 19 August 2013

\begin{abstract}
A determination criterion was proposed for the number of replications, $r$, and of evaluated progenies, $N_{r}$, given $P$ experimental plots, with $N_{r}=P / r$, and $n$ progenies to be selected; its application was discussed in the selection of progenies of bulk populations, derived from two homozygous parents. For a known heritability at the plot level, $h_{0}^{2}$, there is a critical $n$ below which the gain is greater with selection evaluating $P /(r+1)$ progenies in $r+1$ than $P / r$ progenies in r replications. Different $h_{0}^{2}$ scenarios were simulated in the $F_{2}$ and $F_{\infty}$ generations, assuming no dominance. It was demonstrated that at any $h_{0}^{2}$, if $n>18.5 \%$ of $P$, larger gains are obtained by assuming $N_{r}=P$, showing that the augmented block design could be used in the early stages of breeding programs. The higher $h_{0}^{2}$, the higher must be the selection intensity to justify the use of additional replications.
\end{abstract}

Key words: Selection gains, population sample size, number of selected progenies, selection limits.

\section{INTRODUCTION}

In plant breeding, due to limitations in the experimental area or available resources, it is impossible to evaluate experiments with the number of replications and number of progenies desirable for breeders. In the process of developing inbred lines, be it for cultivars or as hybrid parents, a limited number of progenies may undermine the representativeness of genetic variability, whereas a small number of replications can compromise the experimental accuracy. Both situations contribute to reduce genetic gain with selection (GS).

To overcome this problem, considerable research effort has been invested, to identify the best way to manage, sample and/or evaluate segregating populations, with previously available experimental results for some crops. In the case of common bean, for example, success with selection in biparental crossings can be obtained by any method of population management, although due to operational ease and flexibility, the population (or bulk) and single seed descent (SSD) method are most advantageous (Raposo et al. 2000). In addition, at least 100 progenies should be evaluated to represent the genetic variability of a population satisfactorily and to ensure successful selection, according to the experimental conditions of breeding programs (Ferreira et al. 2000).
The number of replications and/or, the ideal plot size to estimate genetic parameters or compare progenies and/or cultivars, were also investigated and satisfactorily determined, varying with the crop and trait considered (Storck et al. 2007, Vieira and Silva 2008, Leite et al. 2009, Cargnelutti Filho et al. 2010, Silva et al. 2011, Storck et al. 2011 and Cargnelutti Filho et al. 2012).

Another aspect is the difficulty of measuring the accuracy of a test appropriately, since the efficiency of the experimental coefficient of variation, the most widely used criterion, is questionable, and the use of selective accuracy is preferable (Resende and Duarte 2007).

In fact, the interest of breeders is to maximize the GS and according to Kempton and Fox (1997), it is necessary to consider: i) the number and choice of parental crosses, ii) the number of replications per experiment and the number of evaluated locations, the size of the improvement program and the proportion of progenies selected at each stage. These authors mention the constant doubt, whether screening a large number of progenies or a more accurate evaluation with fewer progenies using more replications should be preferred. They claim that two or three replications can be used, when enough seeds are available.

When the experimental area is limited, the use of more replications implies in a reduction of the number of progenies.

\footnotetext{
${ }^{1}$ Embrapa Arroz e Feijão - Núcleo do Algodão do Cerrado, Rodovia GO-462, km 12, CP 179, 75.375-000, Santo Antônio de Goiás, GO, Brazil.

*E-mail: joao.silva-filho@embrapa.br
} 
From the GS equation, Bos and Caligari (2008) compared gains by selection using one or more than one observation per progeny, with a fixed number of plots and of selected progenies. The authors show that it is not always advantageous to increase the number of replications instead of the number of evaluated progenies.

In breeding programs, frequently a number of progenies to be selected has to be determined, especially in the early stages. This number must not be so large that the installation of a test network would become unfeasible, nor so small that studies of genotype $\mathrm{x}$ environment interaction and cultivar recommendation for different environments would be affected.

In this study the idea proposed by Bos and Caligari (2008) was extended to decisions between the assessment of $P / r$ progenies with $r$ replications or $P /(r+1)$ progenies with $r+1$ replications, which varies according to the heritability at the plot level. The selection of progenies taken from bulk populations, derived from biparental crosses of homozygous parents was discussed, considering no dominance, although, theoretically, the criterion could be applied to other breeding strategies.

\section{MATERIAL AND METHODS}

\section{Theory}

Let $\mathrm{P}$ be plots available, $N_{r}$ progenies with $r$ replications, such that $P=N_{r} \cdot r$, and $n$ the number of selected progenies. Hence, if $r=1$, then $N_{r}=P$, and the percentage of truncated selection, $t$, is given by: $t_{0}=\frac{n}{P}$. For any $r$ :

$$
\begin{aligned}
& \mathrm{N}_{\mathrm{r}}=\frac{\mathrm{P}}{\mathrm{r}}(1) \\
& \mathrm{t}_{(\mathrm{r})}=\frac{\mathrm{n}}{\mathrm{P} / \mathrm{r}}=\frac{\mathrm{n} \cdot \mathrm{r}}{\mathrm{P}}(2)
\end{aligned}
$$

Then, for each replication being additionally included in the experiment, maintaining $P$ plots:

$$
\begin{aligned}
& \mathrm{N}_{(\mathrm{r}+1)}=\frac{\mathrm{P}}{\mathrm{r}+1}(3) \\
& \mathrm{t}_{(\mathrm{r}+1)}=\frac{\mathrm{n}}{\mathrm{P} /(\mathrm{r}+1)}=\frac{\mathrm{n}(\mathrm{r}+1)}{\mathrm{P}}=\frac{\mathrm{n} \cdot \mathrm{r}}{\mathrm{P}}+\frac{\mathrm{n}}{\mathrm{P}}=\mathrm{t}_{(\mathrm{r})}+\mathrm{t}_{0}
\end{aligned}
$$

When $n$ is constant, $\mathrm{t}_{(r+1)}>\mathrm{t}_{(r)}$. Thus, the ratio between $t_{(r+1)}$ and $t_{(r)}$ is given by:

$d_{t(r)}=\frac{t_{(r+1)}}{t_{(r)}}=\frac{t_{(r)}+t_{0}}{t_{(r)}}=1+\frac{n / P}{n \cdot r / P}=1+\frac{1}{r}=\frac{r+1}{r}$
If the progeny effects are random, the narrow-sense heritability at the plot level is:

$\mathrm{h}_{0}^{2}=\frac{\sigma_{\mathrm{a}}^{2}}{\sigma_{\mathrm{e}}^{2}+\sigma_{\mathrm{a}}^{2}}$

where $\sigma_{\mathrm{a}}^{2}$ is the additive genetic variation and $\sigma_{\mathrm{e}}^{2}$ the residual variance. Assuming the denominator of equation (6) as 1 , then: $h_{0}^{2}=\sigma_{\mathrm{a}}^{2}$ and $\sigma_{\mathrm{e}}^{2}=1-h_{0}^{2}$. In experiments with $r$ replications, the heritability $\left(h_{0}^{2}\right)$ and phenotypic standard deviation $\left(\sigma_{\mathrm{r}}\right)$ in the mean of observations are given by:

$$
\mathrm{h}_{\mathrm{r}}^{2}=\frac{\mathrm{rh}_{0}^{2}}{1+\mathrm{h}_{0}^{2}(\mathrm{r}-1)}
$$

$\sigma_{\mathrm{r}}=\sqrt{\frac{\left(1-\mathrm{h}_{0}^{2}\right)}{\mathrm{r}}+\mathrm{h}_{0}^{2}}$

From the equation of $G S$, using standard deviations $i$, the use of $r_{2}$ replications instead of $r_{1}$, for $r_{2}>r_{l}$, must satisfy the condition $G S_{2}>G S_{1}$ to be beneficial:

$i_{2} h_{2}^{2} \sigma_{2}>i_{1} h_{1}^{2} \sigma_{1}$

$\mathrm{i}_{2}\left[\frac{\mathrm{r}_{2} \mathrm{~h}_{0}^{2}}{1+\mathrm{h}_{0}^{2}\left(\mathrm{r}_{2}-1\right)}\right] \sqrt{\frac{\left(1-\mathrm{h}_{0}^{2}\right)}{\mathrm{r}_{2}}+\mathrm{h}_{0}^{2}} \geq \mathrm{i}_{1}\left[\frac{\mathrm{r}_{1} \mathrm{~h}_{0}^{2}}{1+\mathrm{h}_{0}^{2}\left(\mathrm{r}_{1}-1\right)}\right] \sqrt{\frac{\left(1-\mathrm{h}_{0}^{2}\right)}{\mathrm{r}_{1}}+\mathrm{h}_{0}^{2}}$

$\mathrm{i}_{2}\left[\frac{\mathrm{r}_{2} \mathrm{~h}_{0}^{2}}{1+\mathrm{h}_{0}^{2}\left(\mathrm{r}_{2}-1\right)}\right] \sqrt{\frac{1-\mathrm{h}_{0}^{2}+\mathrm{r}_{2} \mathrm{~h}_{0}^{2}}{\mathrm{r}_{2}}} \geq \mathrm{i}_{1}\left[\frac{\mathrm{r}_{1} \mathrm{~h}_{0}^{2}}{1+\mathrm{h}_{0}^{2}\left(\mathrm{r}_{1}-1\right)}\right] \sqrt{\frac{1-\mathrm{h}_{0}^{2}+\mathrm{r}_{1} \mathrm{~h}_{0}^{2}}{\mathrm{r}_{1}}}$

$\mathrm{i}_{2}\left[\frac{\mathrm{r}_{2} \mathrm{~h}_{0}^{2}}{1+\mathrm{h}_{0}^{2}\left(\mathrm{r}_{2}-1\right)}\right] \sqrt{\frac{1+\mathrm{h}_{0}^{2}\left(\mathrm{r}_{2}-1\right)}{\mathrm{r}_{2}}} \geq \mathrm{i}_{1}\left[\frac{\mathrm{r}_{1} \mathrm{~h}_{0}^{2}}{1+\mathrm{h}_{0}^{2}\left(\mathrm{r}_{1}-1\right)}\right] \sqrt{\frac{1+\mathrm{h}_{0}^{2}\left(\mathrm{r}_{1}-1\right)}{\mathrm{r}_{1}}}$

$\mathrm{i}_{2}\left[\frac{\sqrt{\mathrm{r}_{2}} \mathrm{~h}_{0}^{2}}{\sqrt{1+\mathrm{h}_{0}^{2}\left(\mathrm{r}_{2}-1\right)}}\right] \geq \mathrm{i}_{1}\left[\frac{\sqrt{\mathrm{r}_{1}} \mathrm{~h}_{0}^{2}}{\sqrt{1+\mathrm{h}_{0}^{2}\left(\mathrm{r}_{1}-1\right)}}\right]$

$\mathrm{i}_{2}\left[\frac{\sqrt{\mathrm{r}_{2}}}{\sqrt{1+\mathrm{h}_{0}^{2}\left(\mathrm{r}_{2}-1\right)}}\right] \geq \mathrm{i}_{1}\left[\frac{\sqrt{\mathrm{r}_{1}}}{\sqrt{1+\mathrm{h}_{0}^{2}\left(\mathrm{r}_{1}-1\right)}}\right]$

$\frac{\mathrm{i}_{2}}{\mathrm{i}_{1}} \geq \frac{\sqrt{\mathrm{r}_{1}\left[1+\mathrm{h}_{0}^{2}\left(\mathrm{r}_{2}-1\right)\right]}}{\sqrt{\mathrm{r}_{2}\left[1+\mathrm{h}_{0}^{2}\left(\mathrm{r}_{1}-1\right)\right]}}(9)$

If $n$ corresponds to a percentage $\mathrm{t}_{(\mathrm{r})}$ when $r$ replications are used, $\left(\frac{r+1}{r}\right) t_{(r)}$ is the percentage of selection when

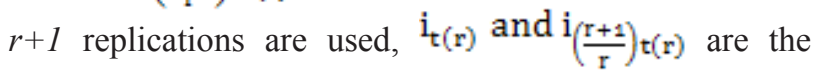
respective values of the standardized selection intensities and $\mathrm{d}_{\mathrm{i}(\mathrm{t})}$ the critical ratio between them. Assuming $r_{l}=r$ and $\mathrm{r}_{2}=r+1,(9)$ can be re-expressed as: 


$$
d_{i(t)}=\frac{i_{\left(\frac{r+1}{r}\right) \cdot t(r)}}{i_{t(r)}}=\frac{\sqrt{r\left[1+h_{0}^{2} r\right]}}{\sqrt{(r+1)\left[1+h_{0}^{2}(r-1)\right]}}
$$

Then, there is a critical value for $\mathrm{n}, \mathrm{n}_{\mathrm{c}(\mathrm{r})}$, below which $G S$ is larger when $\mathrm{r}+1$ replications are used and $\mathrm{N}_{(\mathrm{r}+1)}$ progenies instead of $\mathrm{r}$ replicates and $\mathrm{N}_{\mathrm{r}}$ progenies, which can be determined by choosing two critical selection percentages, $t_{c(r)}$ and $t_{c(r+1)}$, which satisfy the values $d_{t(r)}(5)$ and $\mathrm{d}_{\mathrm{i}(\mathrm{t})}(10)$.

Let, for example, $\mathrm{n}_{\mathrm{c}(\mathrm{r})}$ be determined in a way that the use of two replications, $\mathrm{r}+1=2$, is advantageous for a single observation, $\mathrm{r}=1$; then, $\mathrm{d}_{\mathrm{t}(\mathrm{r})}=2$ and $d_{i(t)}=\frac{\mathrm{i}_{2 \mathrm{t}(\mathrm{r})}}{\mathrm{i}_{\mathrm{t}(\mathrm{r})}}=\sqrt{\frac{1+\mathrm{h}_{0}^{2}}{2}}$. For illustration, assuming a very low $h_{0}^{2}$, tending to zero, $\mathrm{d}_{\mathrm{i}(\mathrm{t})}=0.707$. The two selection ratios that meet $\mathrm{d}_{\mathrm{t}(\mathrm{r})}=2$ and $\mathrm{d}_{\mathrm{i}(\mathrm{t})}=0.707$ were $18.5 \%\left(\mathrm{i}_{\mathrm{t}(\mathrm{r})}\right.$ $\left.=\mathrm{i}_{18.5 \%}=1.443\right)$ and $37.0 \%\left(\mathrm{i}_{2 \mathrm{tr} r}=\mathrm{i}_{37 \%}=1.020\right)$. Thus, $\mathrm{t}_{\mathrm{c}(\mathrm{r})}=18.5 \%$ and $\mathrm{t}_{\mathrm{c}(\mathrm{r}+1)}=37.0 \%$ and . So, theoretically, for $n>18.5 \%$ of $\mathrm{P}$, gains are larger when an increase in the number of progenies is prioritized, $\mathrm{N}_{\mathrm{r}}=\mathrm{P}$, even when $h_{0}^{2}$ is low.

\section{Simulation}

An availability of 600 experimental plots was taken into consideration and the following arrangements were compared: a) $\mathrm{N}_{\mathrm{r}}=600$ progenies and $\mathrm{r}=1$ vs. $\mathrm{N}_{(\mathrm{r}+1)}=300$ progenies $\mathrm{r}+1=2$; b) $\mathrm{N}_{\mathrm{r}}=300$ and $\mathrm{r}=2$ vs. $\mathrm{N}_{(\mathrm{r}+1)}=200$ and $\mathrm{r}+1=3$; c) $\mathrm{N}_{\mathrm{r}}=200$ and $\mathrm{r}=3$ vs. $\mathrm{N}_{(\mathrm{r}+1)}=150$ for $\mathrm{r}+1$ $=4$. Equation (9) can be used for any two replications $r_{1}$ and $r_{2}$. However, in this article, only consequences of the decision to use a single additional replication are pointed out (Equation 10).

The purpose was to validate by simulation, at different $h_{0}^{2}$ levels, whether $\mathrm{n}_{\mathrm{cr})}$ is a good criterion to decide about using $\mathrm{r}$ or $\mathrm{r}+1$ replications for $\mathrm{N}_{\mathrm{r}}$ and $\mathrm{N}_{(\mathrm{r}+1)}$ evaluated progenies, respectively, given the selection objective of $n$ progenies. Simulations with $\mathrm{n}_{\mathrm{c}(\mathrm{r})}, \mathrm{n}_{\mathrm{c}(\mathrm{r})}+2 \% \cdot \mathrm{N}_{\mathrm{r}}$ and $\mathrm{n}_{\mathrm{c}(\mathrm{r})}$ $-2 \% \cdot \mathrm{N}_{\mathrm{r}}$ selected progenies were performed. If $\mathrm{n}_{\mathrm{c}(\mathrm{r})}$ is a good criterion, it is expected that GS for $\mathrm{n}_{\mathrm{c}(\mathrm{r})}+2 \% \cdot \mathrm{N}_{\mathrm{r}}$ is greater in a scenario with $N_{r}$ and $r$ and the GS for $\mathrm{n}_{\mathrm{c}(\mathrm{r})}-2 \%$ $\cdot \mathrm{N}_{\mathrm{r}}$ would be greater with $N_{r+1}^{r}$ and $r+1$. In the selection of $\mathrm{nc}_{\mathrm{r}}$ progenies, similar GS are expected in both situations.

Three levels of $h_{0}^{2}(0.2,0.35,0.50)$ were simulated using SAS/IML software. A bulk base population was considered, derived from a cross between contrasting homozygous parents without dominance and 50 genes controlling the trait, independent and with equal value and plants sampled in the $\mathrm{F}_{2}\left(\mathrm{~F}_{2: 3}\right.$ progenies $)$ and $F_{\infty}$, generation (homozygous lines). Favorable homozygotes
(AA) were assigned value 1 and unfavorable homozygous (aa) -1 , while heterozygotes (Aa) were assigned 0 . In the $\mathrm{F}_{2}$ generation, the heterozygous genotype frequency was assumed as 0.5 and homozygote frequency as 0.25 . In $F_{\infty}, 0.5$ was assumed as genotypic frequency value of homozygotes. The parametric value of the progenies was assumed to be the arithmetic sum of the values of the 50 loci. Under the simulated conditions, the genetic variance in $\mathrm{F}_{2}$ is 25 and 50 in $F_{\infty}$. Per plot and simulation, a random number was generated from a normal standard distribution, later multiplied by the value of the residual standard deviation, corresponding to the simulated $h_{0}^{2}$, which is the residual plot value. The phenotypic value of each observation was assumed as the sum of the parametric value of the progeny plus the sum of the residual plot value. Estimates of $G S$ were obtained by subtracting the parametric mean of the population from the parametric mean of the selected progenies based on phenotypic values, considering an average of 2000 simulations for each scenario considered for inferences. The mean standard error of $G S$ was also calculated from the values of the 2000 simulations.

\section{Example of a comparison procedure}

$$
600 \text { plots }(\mathrm{P}=600) \text {; }
$$

Compare: 300 progenies with two replications and 200 with three, and $h_{0}^{2}=0.2$; have:

In this case, using Equation 10 with $r=2, r+1=3$, we $\frac{\left.\mathrm{i}_{(\mathrm{r}+1}\right) \mathrm{r}(\mathrm{r})}{\mathrm{i}_{\mathrm{r}(\mathrm{r})}} \geq \frac{\sqrt{\mathrm{r}\left[1+\mathrm{h}_{0}^{2} \mathrm{r}\right]}}{\sqrt{(\mathrm{r}+1)\left[1+\mathrm{h}_{0}^{2}(\mathrm{r}-1)\right]}} \rightarrow \frac{\mathrm{i}_{1,5 \mathrm{t}(\mathrm{r})}}{\mathrm{i}_{\mathrm{t}(\mathrm{r})}} \geq \frac{\sqrt{2[1+(0.2) 2]}}{\sqrt{(2+1)[1+0.2(2-1)]}} \geq 0.882$

The two selection proportions that simultaneously satisfy $\mathrm{d}_{\mathrm{t}(\mathrm{r})}=1.5$ and $\mathrm{d}_{\mathrm{i}(\mathrm{t})}=0.882$ are $10.6 \%$ and $15.9 \%$. So, $\mathrm{t}_{\mathrm{c}(\mathrm{r})}=10.6 \%$, and $\mathrm{n}_{\mathrm{c}(\mathrm{r})}=\mathrm{t}_{\mathrm{c}(\mathrm{r})} \cdot(\mathrm{P} / \mathrm{r})=0.106 \times 300=31$. If the parametric $\mathrm{n}_{\mathrm{c}(\mathrm{r})}$ is really close to 31 , it is expected that the GS of 37 progenies $(31+2 \%$ of 300$)$ is higher when 300 progenies are evaluated with two replications and the $G S$ of 25 progenies ( $31-2 \%$ of 300 ) is greater than 200 when evaluated with three replications.

\section{RESULTS AND DISCUSSION}

\section{Critical selection proportions for different heritability levels}

The values of $\mathrm{d}_{\mathrm{i}(\mathrm{t})}$ and the corresponding $\mathrm{t}_{\mathrm{c}(\mathrm{r})}$ and $\mathrm{t}_{\mathrm{c}(\mathrm{r}+1)}$ were contrasted in five comparisons of the use of an additional replication, at different levels of $h_{0}^{2}$ (Table 1), in other words: 1 replication vs. two, two vs. three, three vs. four, four vs. five five vs. six replications. Deciding between the use of one or two replications means answering the following question: for the same number 
of selected progenies, is the $G S$ larger when sampling the population to the limit of available plots, with a single observation per progeny, or when using half the sample size, but with two observations per progeny, improving the experimental accuracy of selection?

If the chosen strategy is screening or pre-breeding selection, the use of many replications is unnecessary, even when $h_{0}^{2}$ is low. As a rule, the higher $h_{0}^{2}$, the more intense selection has to be to justify the use of additional replications. For a given $h_{0}^{2}, \mathrm{n}_{\mathrm{c}(\mathrm{r})}$ can be obtained by making $\mathrm{n}_{\mathrm{c}(\mathrm{r})}=\mathrm{t}_{\mathrm{c}(\mathrm{r})} \cdot(\mathrm{P} / \mathrm{r})$. If $h_{0}^{2},=0.1, \mathrm{r}=1$ and $\mathrm{r}+1=2$, the values of $\mathrm{t}_{\mathrm{c}(\mathrm{r})}$ and $\mathrm{t}_{\mathrm{c}(\mathrm{r}+1)}$ are, respectively, $15.4 \%$ and $30.8 \%$, for any desired $n$, if $n / N_{r}<15.4 \%$ (or $n / N_{r+1}<30.8 \%$ ), then, $G S$ for $\mathrm{N}_{\mathrm{r}+1}>G S$ with $\mathrm{N}_{\mathrm{r}}$, preferably evaluating $\mathrm{N}_{\mathrm{r}+1}$ in $\mathrm{r}+1$ replications.

Our results are consistent with those presented by Bos and Caligari (2008). Assuming $h_{0}^{2}=0.5$, it was observed that gains for $\mathrm{r}+1=2$ were only superior to $\mathrm{r}=1$ if $\mathrm{t}_{\mathrm{c}(\mathrm{r})}<$ $3.8 \%$ (Table 1). For $h_{0}^{2}=0.5$ and $v \geq 4 \%(v=n / P$ in Bos and Caligari (2008)), higher gains were obtained with one observation than with two ( $v_{j}$ for $J=2$ in the said study); when $v \leq 3 \%$, higher gains were obtained with two replications. Similarly, when $\mathrm{r}=1, \mathrm{r}+1=2$ and $h_{0}^{2} \leq 0.4$, the use of two replications is advantageous, provided that the selection intensity is $<6.3 \%$, as also reported by Bos and Caligari (2008). In the table presented by these authors, at $h_{0}^{2} \leq 0.4$, the gains with $v_{j}$, for $\mathrm{J}=2$ were always greater than with a single observation per progeny for all $v$ values $(0.5 \%, 1 \%, 2 \%, 3 \%, 4 \%, 5 \%$, or $6 \%)$. The advantage of the table presented here is to directly provide the selection ratio limit to decide on whether to use $\mathrm{N}_{\mathrm{r}}$ or $\mathrm{N}_{\mathrm{r}+1}$ progenies, facilitating decision making.

The use of two or three replications suggested by Kempton and Fox (1997) was also corroborated by the data (see Table 1). Assuming $h_{0}^{2}=0.2$, the use of four replications $\mathrm{r}$ $+1=4$, or instead of three, $r=3$, would only be advantageous if $\mathrm{n} / \mathrm{N}_{\mathrm{r}}<8.7 \%$ (or $\left.\mathrm{n} / \mathrm{N}_{\mathrm{r}+1}<11.6\right)$.

Summaries of sampling information $\left(\mathrm{P}, \mathrm{r}\right.$ and $\mathrm{r}+1, \mathrm{~N}_{\mathrm{r}}$ and $\mathrm{N}_{\mathrm{r}+1}, h_{0}^{2}, h_{\mathrm{r}}^{2}$ and $\left.h_{\mathrm{r}+1}^{2}\right)$ and theoretical critical values $\left(\mathrm{d}_{\mathrm{t}(\mathrm{r})}, \mathrm{d}_{\mathrm{i}(\mathrm{t})}\right.$, $t_{c(r)}$ and $\left.t_{c(r+1)}, n_{c(r)}\right)$ for each of the simulated comparisons are shown in Table 2. Assuming 600 plots $(\mathrm{P}=600)$ and selection of 30 progenies $(n=30)$, would it be more advantageous to choose 30 among 600 progenies, with a single observation ( $5 \%$ selection), or choose 30 of 300 ( $10 \%$ selection), but evaluated with two replications?

It was shown that if $h_{0}^{2}=0.35: h_{\mathrm{r}}^{2}=0.35$ (heritability of 600 evaluated progenies $\mathrm{r}=1$ ), $h_{\mathrm{r}+1}^{2}=0.519$ (heritability of 300 progenies $\mathrm{r}+1=2) ; \mathrm{t}_{\mathrm{c}(\mathrm{r})}=7.6 \%$ and $\mathrm{t}_{\mathrm{c}(\mathrm{r}+1)}=15.2 \%$ and $\mathrm{n}_{\mathrm{c}(\mathrm{r})}=0.076 \times 600=45$. Since $30<\mathrm{n}_{\mathrm{c}(\mathrm{r})}$, it would be convenient to select 30 out of 300 , because the gain in accuracy compensates the lower selection intensity. If $h_{0}^{2}=$ $0.5, h_{\mathrm{r}}^{2}=0.5, h_{\mathrm{r}+1}^{2}=0.667 ; \mathrm{t}_{\mathrm{c}(\mathrm{r})}=3.7 \%$ and $\mathrm{t}_{\mathrm{c}(\mathrm{r}+1)}=7.4 \%$, $\mathrm{n}_{\mathrm{c}(\mathrm{r})}=22$, then it is best to select 30 among 600 because, in this case $30>\mathrm{nc}_{\mathrm{r}}$.

For models in which the random effects are only progenies and the experimental error of the selective accuracy is the square root of heritability at the mean progeny level (Equation 7); in the case of other random effects in the model, the selective accuracy is influenced by the magnitude of the variances of these effects. Further details are given by Mrode (2005). In these examples, a small variation in heritability (0.15) modified the choice of the experimental strategy. Therefore, the more accurate the heritability estimates, the more reliable is the proposed criterion.

Table 1. Critical ratios between standardized selection intensities $\left(\mathrm{d}_{\mathrm{j}(\mathrm{t})}\right)$ and critical percentages of selection for the use of $\mathrm{r}$ or $\mathrm{r}+1 \mathrm{replications}\left(\mathrm{t}_{\mathrm{cr} r \mathrm{l}}\right.$ and $\left.\mathrm{t}_{\mathrm{c}(\mathrm{r}+1)}\right)$, at different heritabilities at the plot level $\left(h_{0}^{2}\right)$, in five comparisons using an additional replication: $\mathrm{r}=1 \mathrm{vs} . \mathrm{r}+1=2 ; \mathrm{r}=2 \mathrm{vs} . \mathrm{r}+1=3, \mathrm{r}=3 \mathrm{vs}$. $\mathrm{r}+1+1=4, r=4$ vs. $r+1=5$ and $r=5$ vs. $r+1=6$

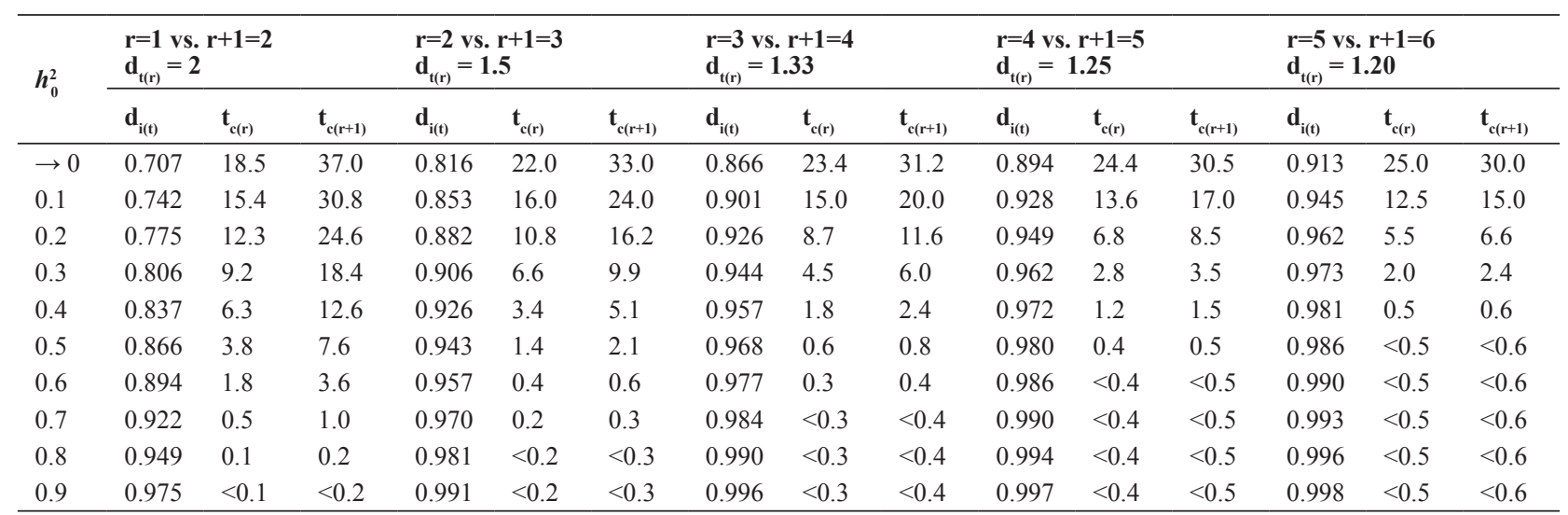


The comparisons of $300(\mathrm{r}=2)$ versus $200(\mathrm{r}+1=3)$ were performed for $h_{0}^{2}=0.2$ and 0.35 and for $200(\mathrm{r}=3)$ versus $150(\mathrm{r}+1=4)$ only for $h_{0}^{2}=0.2$, since it was theoretically expected that a number of plots well over 600 would be required for safe simulations of the comparisons, since $\mathrm{t}_{\mathrm{c}(\mathrm{r})}$ was very low.

\section{RESULTS OF SIMULATIONS}

The results for different scenarios of $h_{0}^{2}, \mathrm{n}$ and $\mathrm{N}_{\mathrm{r}}(600$, $300,200,150$, with $\mathrm{r}$ replications) are shown in Table 3 . As expected, in the same $\mathrm{Nr}$, type of population and $h_{0}^{2}$, larger GS was obtained with greater selection intensity (lower $n$ values). A positive effect on GS of the increase in $h_{0}^{2}$, under the same selection intensity, was also observed. For 600 or 300 evaluated plants, the GS with $\mathrm{n}=34$, when $h_{0}^{2}=0.5$, was higher than GS with $\mathrm{n}=33$, when $h_{0}^{2}=0.35$.

There was perfect correlation between the results of simulations and the $\mathrm{n}_{\mathrm{c}(\mathrm{r})}$ determined by the criteria described (represented by “*” in Table 3). Comparing the GS of $\mathrm{N}_{\mathrm{r}}$ with $\mathrm{N}_{\mathrm{r}+1}$, at any $h_{0}^{2}$ in the $\mathrm{F}_{2}$ or $\mathrm{F}_{\infty}$ populations, it was shown

Table 2. Number of plots (P), number of evaluated progenies $\left(\mathrm{N}_{\mathrm{r}}\right.$ and $\left.\mathrm{N}_{\mathrm{r}+1}\right)$ with $\mathrm{r}$ and $\mathrm{r}+1$ replications, heritability at the plot level $\left(h_{0}^{2}\right)$, and the progeny mean in $\mathrm{N}_{\mathrm{r}}\left(h_{\mathrm{r}}^{2}\right)$ and $\mathrm{N}_{\mathrm{r}+1}\left(h_{\mathrm{r}+1}^{2}\right)$, critical selection percentages in $\mathrm{N}_{\mathrm{r}}$ and $\mathrm{N}_{\mathrm{r}+1}\left(\mathrm{t}_{\mathrm{c}(\mathrm{r})}\right.$ and $\left.\mathrm{t}_{\mathrm{c}(\mathrm{r}+1)}\right)$, the ratio between $\mathrm{t}_{\mathrm{c}(\mathrm{r})}$ and $\mathrm{t}_{\mathrm{c}(\mathrm{r}+1)}\left(\mathrm{d}_{\mathrm{t}(\mathrm{r})}\right)$, the ratio between the intensities of standardized selection of $t_{c(r)}$ and $t_{c(r+1)}\left(d_{i(t)}\right)$, the critical value of the number of selected progenies using $r$ replications $\left(\mathrm{n}_{c(r)}\right)$ for the different simulated scenarios

\begin{tabular}{|c|c|c|c|c|c|c|c|c|c|c|c|c|}
\hline $\mathbf{P}$ & $\mathbf{N}_{\mathbf{r}}$ & $\mathbf{N}_{\mathrm{r}+1}$ & $\mathbf{R}$ & $\mathbf{r + 1}$ & $h_{0}^{2}$ & $h_{\mathrm{r}}^{2}$ & $h_{r+1}^{2}$ & $d_{t(r)}$ & $d_{i(t)}$ & $\mathbf{t}_{\mathrm{c}(\mathrm{r})}$ & $\mathbf{t}_{\mathrm{c}(\mathrm{r}+1)}$ & $\mathbf{n}_{\mathrm{c}(\mathbf{r})}$ \\
\hline 600 & 600 & 300 & 1 & 2 & 0.35 & 0.350 & 0.519 & 2.00 & 0.822 & 7.6 & 15.2 & 45 \\
\hline 600 & 300 & 200 & 2 & 3 & 0.20 & 0.333 & 0.429 & 1.50 & 0.882 & 10.6 & 15.9 & 31 \\
\hline 600 & 300 & 200 & 2 & 3 & 0.35 & 0.519 & 0.618 & 1.50 & 0.916 & 4.8 & 7.2 & 14 \\
\hline 600 & 300 & 200 & 2 & 3 & 0.50 & 0.667 & 0.750 & 1.50 & 0.943 & 1.4 & 2.1 & 4 \\
\hline 600 & 200 & 150 & 3 & 4 & 0.35 & 0.618 & 0.683 & 1.33 & 0.951 & 2.7 & 3.6 & 5 \\
\hline 600 & 200 & 150 & 3 & 4 & 0.50 & 0.750 & 0.800 & 1.33 & 0.968 & 0.6 & 0.8 & 1 \\
\hline
\end{tabular}

Table 3. Selection gains and their standard errors (in parentheses) obtained for open bulk in $\mathrm{F}_{2}$ and $\mathrm{F}_{\infty}$ generation, at different heritabilities at the plot level $\left(h_{0}^{2}\right)$, number of selected progenies $(\mathrm{n})$, selection percentage when $\mathrm{r}\left(\mathrm{PS}_{\mathrm{r}}\right)$ and $\mathrm{r}+1\left(\mathrm{PS}_{\mathrm{r}+1}\right)$ replications are used and number of evaluated progenies with $\mathrm{r}\left(\mathrm{N}_{\mathrm{r}}\right)$ and $\mathrm{r}+1\left(\mathrm{~N}_{\mathrm{r}+1}\right)$ replications, assuming 50 genes controlling the character, allele frequency of 0.5 and absence of dominance

\begin{tabular}{|c|c|c|c|c|c|c|c|}
\hline \multirow{2}{*}{$h_{0}^{2}$} & \multirow{2}{*}{$\mathrm{n}$} & \multirow{2}{*}{$\mathrm{PS}_{\mathrm{r}}$} & \multirow{2}{*}{$\mathrm{PS}_{\mathrm{r}+1}$} & \multicolumn{2}{|c|}{ Open bulk in $\mathrm{F}_{\infty}$} & \multicolumn{2}{|c|}{ Open bulk in $\mathrm{F}_{2}$} \\
\hline & & & & $\mathrm{N}_{\mathrm{r}}=600 ; \mathrm{r}=1$ & $\mathrm{~N}_{\mathrm{r}+1}=300 ; \mathrm{r}+1=2$ & $\mathrm{~N}_{\mathrm{r}}=600 ; \mathrm{r}=1$ & $\mathrm{~N}_{\mathrm{r}+1}=300 ; \mathrm{r}+1=2$ \\
\hline \multirow{2}{*}{0.2} & 61 & 10.2 & 20.4 & $5.53(0.018)$ & $5.65(0.016)$ & $3.91(0.013)$ & $4.00(0.011)$ \\
\hline & 85 & 14.2 & 28.4 & $4.99(0.015)$ & $4.86(0.013)$ & $3.54(0.010)$ & 3.44 (0.009) \\
\hline \multirow[b]{2}{*}{0.35} & 33 & 5.5 & 11.0 & $8.41(0.023)$ & $8.65(0.020)$ & $5.97(0.016)$ & $6.15(0.014)$ \\
\hline & $45^{*}$ & 7.5 & 15.0 & $7.87(0.019)$ & $7.89(0.017)$ & $5.55(0.014)$ & $5.57(0.012)$ \\
\hline \multirow{3}{*}{0.5} & 10 & 1.7 & 3.4 & $12.29(0.038)$ & $12.65(0.036)$ & $8.69(0.027)$ & $9.00(0.024)$ \\
\hline & $22 *$ & 3.7 & 7.4 & $10.85(0.026)$ & $10.87(0.023)$ & $7.67(0.019)$ & $7.68(0.016)$ \\
\hline & 34 & 5.7 & 11.4 & $9.99(0.020)$ & $9.74(0.019)$ & $7.06(0.015)$ & $6.88(0.013)$ \\
\hline$h_{0}^{2}$ & $\mathrm{n}$ & $\mathrm{PS}_{\mathrm{r}}(\%)$ & $\mathrm{PS}_{\mathrm{r}+1}(\%)$ & $\mathrm{N}_{\mathrm{r}}=300 ; \mathrm{r}=2$ & $\mathrm{~N}_{\mathrm{r}+1}=200 ; \mathrm{r}+1=3$ & $\mathrm{~N}_{\mathrm{r}}=300 ; \mathrm{r}=2$ & $\mathrm{~N}_{\mathrm{r}+1}=200 ; \mathrm{r}+1=3$ \\
\hline 0.2 & 25 & 8.3 & 12.5 & $7.47(0.026)$ & $7.56(0.024)$ & $5.26(0.019)$ & $5.33(0.017)$ \\
\hline 0.35 & 20 & 6.7 & 10.0 & $9.80(0.027)$ & $9.69(0.025)$ & $6.95(0.019)$ & $6.81(0.018)$ \\
\hline$h_{0}^{2}$ & $\mathrm{n}$ & $\mathrm{PS}_{\mathrm{r}}(\%)$ & $\mathrm{PS}_{\mathrm{r}+1}(\%)$ & $\mathrm{N}_{\mathrm{r}}=200 ; \mathrm{r}=3$ & $\mathrm{~N}_{\mathrm{r}+1}=150 ; \mathrm{r}+1=4$ & $\mathrm{~N}_{\mathrm{r}}=200 ; \mathrm{r}=3$ & $\mathrm{~N}_{\mathrm{r}+1}=150 ; \mathrm{r}+1=4$ \\
\hline \multirow{3}{*}{0.2} & 12 & 6.0 & 8.0 & $9.01(0.037)$ & $9.15(0.036)$ & $6.47(0.025)$ & $6.48(0.025)$ \\
\hline & $16^{*}$ & 8.0 & 10.7 & $8.54(0.032)$ & $8.49(0.030)$ & $6.05(0.022)$ & $6.04(0.021)$ \\
\hline & 20 & 10.0 & 13.3 & $8.08(0.027)$ & $8.04(0.026)$ & $5.69(0.020)$ & $5.67(0.019)$ \\
\hline
\end{tabular}

$* \mathrm{n}_{\mathrm{c}(\mathrm{r})}$ 
that GS with $\mathrm{N}_{\mathrm{r}}$ was higher when $\mathrm{n}=\mathrm{n}_{\mathrm{c}(\mathrm{r})}+2 \%$ of $\mathrm{N}_{\mathrm{r}}$, while GS with $\mathrm{N}_{\mathrm{r}+1}$ was higher when $\mathrm{n}=\mathrm{n}_{\mathrm{c}(\mathrm{r})}-2 \%$ of $\mathrm{N}_{\mathrm{r}}$.

It was observed, for example, that at $h_{0}^{2}=0.2$ and $\mathrm{n}=$ 61 (73-2\% of 600$)$, GS was greater for 300 plants and two replications, while for $\mathrm{n}=85(73+2 \%$ of 600$)$, GS with 600 plants and one replication was higher, in both $\mathrm{F}_{2}$ and $\mathrm{F}_{\infty}$.

A comparison of the gains in $\mathrm{F}_{2}$ or $\mathrm{F}_{\infty}$. for the same conditions of $\mathrm{n}, h_{0}^{2}$ and $\mathrm{N}$, clearly showed that gains in $\mathrm{F}_{\infty}$ were approximately $40 \%$ higher than in $\mathrm{F}_{2}$. In this case, the reason is that the gains with selection between the two populations differ only in phenotypic standard deviation. It is known that one additive variance is exploited in selection among $\mathrm{F}_{2: 3}$ progenies, while in $\mathrm{F}_{\infty}$, due to inbreeding, there are two additive variances between lines (Ramalho et al. 1993). Since the experimental error in the simulations was proportional to the magnitude of genetic variances, the phenotypic variance in $\mathrm{F}_{\infty}$, is twice as high as in $\mathrm{F}_{2}$ and therefore, the phenotypic standard deviation is 1.41 times higher (square root of 2).

\section{Implications for the selection strategy}

In the comparison of trials with an equal number of evaluated and selected progenies, selection is more efficient for a higher number of replications, since heritability is higher; however, for a fixed number of plots and selected progenies, the selection intensity and phenotypic standard deviation decrease with increasing number of replications, and the change in response to selection depends on the ratio between these two values (Wricke and Weber 1986).

As shown, there are circumstances where increasing the accuracy by using more replications will not result in higher GS. Ferreira et al. (2000), Pinto et al. (2000), based on the stabilization of genetic parameters, considered sample sizes of 100 progenies as satisfactory in breeding of common bean and of 200 progenies for recurrent selection in maize for traits such as yield, with widely acknowledged low heritability. Resende and Duarte (2007) suggested that the quality evaluation of variety trials should be based on the Snedecor F test values, which should not be less than five to qualify the accuracy of an experiment as high. According to the authors, for traits with $h_{0}^{2}<0.4$, accuracies $>90 \%$ (square root of equation 7) can only be achieved with six or more replications. In this study, at $h_{0}^{2}=0.4$, the use of six instead of five replications is only justified if the selection percentage is $<0.6 \%$, i.e., approximately one progeny selected of every 200 evaluated (Table 1). This means that it may be questionable to scale or qualify experiments according to the selective accuracy or choose the number of progenies to be assessed using the stabilization of genetic parameters as criterion, but ignoring the number of progenies to be selected and the number of plots available.

The use of the augmented block designs for the initial phases of improvement program, suggested elsewhere (Souza et al. 2003, Souza et al. 2006, Peternelli et al. 2009), was also confirmed, since experimental techniques of recovery of interblock and/or intergenotypic information as well as spatial analysis can improve the experimental accuracy without changing the number of replications (Santos et al. 2002, Duarte and Vencovsky 2005). It is worth bearing in mind that the evaluation of the population is a step after the choice of parents, which according to Bernardo (2003) is more important than the number of populations evaluated or the number of progenies.

The feasibility of using a single observation per progeny does not necessarily imply in the use of replications with a single plant. The reason is that plot size and shape influence $h_{0}^{2}$ and vary according to the species and trait under selection. For example, in the evaluation of maize half-sib progenies, considering a same number of plants, the experimental error is better controlled when plots with two or three rows than with a single row are used (Palomino et al. 2000).

\section{FINAL CONSIDERATIONS}

This study evidenced that the decision on the number of progenies to be assessed and the number of replications in situations of a limited plot number, can be made by defining the number of progenies to be selected and the heritability at the plot level. The criterion proposed here for this purpose proved to be sufficiently efficient at different heritability levels, be it in the $\mathrm{F}_{2}$ or $\mathrm{F}_{\infty}$ generation. As a general rule, the higher the heritability, the more intense the selection must be to justify the use of more replications. It was shown that if the desired amount of progenies to be selected is higher than $18.5 \%$ of the number of available plots, gains are higher when prioritizing the number of progenies to be evaluated over number of replications, regardless of the heritability level. The results show the possibility of using an augmented block design in the early stages of breeding programs. 


\section{Otimização do número de progênies e de repetições em experimentos de melhoramento de plantas}

Resumo - Propõe-se um critério de escolha do número de repetições, $r$, e de progênies avaliadas, $N_{r}$, dadas $P$ parcelas experimentais, com $N_{r}=P / r$, e n progênies a serem selecionadas; discute-se sua aplicação na seleção de progênies de populações conduzidas em bulk, oriundas de dois genitores homozigóticos. Conhecida a herdabilidade em nível de parcela, $h_{0}^{2}$, há um $n$ crítico abaixo do qual o ganho com a seleção é maior avaliando-se $P /(r+1)$ progênies com $r+1$ repetições que P/r progênies com $r$. Foram simulados diferentes cenários de $h_{0}^{2}$, nas gerações $F_{2}$ e $F_{\infty}$, considerando-se ausência de dominância. Mostra-se que, sob qualquer valor de $h_{0}^{2}$, se $n>18.5 \%$ de $P$, maiores ganhos são obtidos tomando-se $N_{r}=P$, evidenciando a possibilidade do uso de delineamento em blocos aumentados em fases iniciais de programas de melhoramento. Quanto maior $h_{0}^{2}$, seleções mais intensas são necessárias para justificar o uso adicional de repetições.

Palavras-chave: Ganhos com a seleção, tamanho amostral populacional, número de progênies selecionadas, limites da seleção.

\section{REFERENCES}

Bernardo R (2003) Parental selection, number of breeding populations, and size of each population in inbred development. Theoretical and Applied Genetics 107: 1252-1256.

Bos I and Caligari P (2008) Selection methods in plant breeding. $2^{\text {nd }}$ ed., Springer, Dordrecht, 471p.

Cargnelutti Filho A, Marchesan E, Silva LS and Toebe M (2012) Medidas de precisão experimental e do número de repetições em ensaios de genótipos de arroz irrigado. Pesquisa Agropecuária Brasileira 47: 336-343.

Cargnelutti Filho A, Storck L and Guadagnin JP (2010) Número de repetições para comparação de cultivares de milho. Ciência Rural 40: 1023-1030.

Duarte JB and Vencovsky R (2005) Spatial statistical analysis and selection of genotypes in plant breeding. Pesquisa Agropecuária Brasileira 40: $107-114$.

Ferreira WD, Ramalho MAP, Ferreira DF and Souza MA (2000) Family number in common bean selection. Genetics and Molecular Biology 23: 403-409.

Kempton RA and Fox PN (1997) Introduction. In Kempton RA and Fox PN (Eds) Statistical methods for plant variety evaluation. Chapman and Hall, London, p.1-8.

Leite MSO, Peternelli LA, Barbosa MHP, Cecon PR and Cruz CD (2009) Sample size for full-sib family evaluation in sugarcane. Pesquisa Agropecuária Brasileira 44: 1562-1574.

Mrode RA (2005) Linear models for the prediction of animal breeding values. $2^{\text {nd }}$ ed., CABI International, Wallingford, $368 \mathrm{p}$.

Palomino EC, Ramalho MAP and Ferreira DF (2000) Tamanho da amostra para famílias de meios-irmãos de milho. Pesquisa Agropecuária Brasileira 35: 1433-1439.

Peternelli LA, Souza EFM, Barbosa MHP and Carvalho MP (2009) Delineamentos aumentados no melhoramento de plantas em condições de restrições de recursos. Ciência Rural 39: 2425-2430.
Pinto RMC, Lima Neto FP and Souza Junior CLS (2000) Estimativa do número apropriado de progênies $\mathrm{S} 1$ para seleção recorrente em milho. Pesquisa Agropecuária Brasileira 35: 63-73.

Ramalho MAP, Santos JB and Zimmermann MJO (1993) Genética quantitativa em plantas autógamas: aplicações ao melhoramento do feijoeiro. Editora UFG, Goiânia, 271p.

Raposo FV, Ramalho MAP and Abreu AFB (2000) Comparação de métodos de condução de populações segregantes do feijoeiro. Pesquisa Agropecuária Brasileira 35: 1991-1997.

Resende MDV and Duarte JB (2007) Precisão e controle de qualidade em experimentos de avaliação de cultivares. Pesquisa Agropecuária Tropical 37: 182-194.

Santos AH, Bearzoti E, Ferreira DF and Silva Filho JL (2002) Simulation of mixed models in augmented block design. Scientia Agricola 59: 483-489.

Silva AR, Rêgo ER and Cecon PR (2011) Tamanho de amostra para caracterização morfológica de frutos de pimenteira. Horticultura Brasileira 29: 125-129.

Souza EA, Geraldi IO, Ramalho MAP and Bertolucci FLG (2003) Experimental alternatives for evaluation of progenies and clones in Eucalyptus breeding programs. Revista Árvore 27: 427-434.

Souza EFM, Peternelli LA and Barbosa MHP (2006) Designs and model effects definitions in the initial stage of a plant breeding program. Pesquisa Agropecuaria Brasileira 41: 369-375.

Storck L, Lopes SJ, Cargnelutti Filho A, Martini LFD and Carvalho MP (2007) Sample size for single, double and triple hybrid corn ear traits. Scientia Agrícola 64: 30-35.

Storck L, Lopes SJ, Lúcio AC and Cargnelutti Filho A (2011) Optimum plot size and number of replications related to selective precision. Ciência Rural 41: 390-396.

Vieira JV and Silva GO (2008) Tamanho mínimo da parcela para avaliação de caracteres de raiz em cenoura. Bragantia 67: 1047-1052.

Wricke G and Weber WE (1986) Quantitative genetics and selection in plant breeding. Walter of Gruyter, Berlin, 406p. 